\title{
PENINGKATAN KINERJA KEUANGAN PERUSAHAAN MELALUI STRUKTUR MODAL UNTUK MENINGKATKAN NILAI PERUSAHAAN
}

Submitted Date :

2 Februari 2019

Accepted Date :

14 Februari 2019
Harril Brimantyo Universitas Merdeka Malang harril.brimantyo@unmer.ac.id

Ach. Kholilur Rochman Universitas Merdeka Malang pakkhol613@gmail.com

Tsabita Karima Universitas Trisakti karimatsabita8@gmail.com

Suggested Citation:

Modigliani, Franco \& Miller, M.H. 1958. "The Cost of Capital, Corporation Finance and The Theory of Investment". The American Economic Review. 13(3): 261- 297.

\begin{abstract}
:
The purpose of this research are to analyze and explain the effect of capital structure on financial performance and firm value, and the effect of financial performance on firm value. The research method used in this study is quantitative research with an explanatory research approach. The data analyzed by partial least square using 6 property \& real estate companies that are listed on the Indonesia Stock Exchange in 2012-2016 as the research sample. The results of the study indicate that the capital structure has no significant effect on both financial performance and firm value. Financial performance has a significant effect on firm value.
\end{abstract}

Keyword : Capital Structure, Financial Performance, Firm Value

\section{Abstrak:}

Tujuan penelitian ini adalah untuk menganalisis dan menjelasakan pengaruh struktur modal terhadap kinerja keuangan dan nilai perusahaan, serta pengaruh kinerja keuangan terhadap nilai perusahaan. Metode yang digunakan di dalam penelitian ini adalah penelitian kuantitatif dengan pendekatan eksplanatory research. Alat analisis data yang digunakan adalah partial least square dengan menggunakan 6 perusahaan property \& real estate yang listing di Bursa efek Indonesia pada tahun 2012-2016 sebagai sampel penelitian. Hasil penelitian menunjukkan bahwa struktur modal berpengaruh tidak signifikan baik terhadap kinerja keuangan maupun nilai perusahaan. Kinerja keuangan berpengaruh signifikan terhadap nilai perusahaan.

Kata Kunci: Kinerja Keuangan, Nilai Perusahaan, Struktur Modal

JEL Classification : G32, M16, 


\section{Pendahuluan}

Di dalam perdagangan saham pada pasar modal, informasi mengenai kondisi perusahaan (emiten) sangat berharga bagi para investor maupun calon investor. Di antara berbagai informasi yang ada di dalam perusahaan, terdapat beberapa informasi penting terkait dengan perusahaan antara lain adalah informasi mengenai struktur modal, kinerja keuangan dan nilai perusahaan dalam suatu periode atau waktu tertentu yang merupakan bentuk informasi fundamental. Informasi tersebut yang akan mempengaruhi keputusan investasi baik para investor maupun calon investor.

Para pemegang saham yang telah menginvestasikan kekayaannya di suatu perusahaan pada dasarnya menginginkan return yang maksimal. Return yang maksimal akan diperoleh jika perusahaan mampu meningkatkan harga saham yang nantinya akan memberikan kemakmuran bagi pemegang saham. Tingginya harga saham akan memberikan dampak positif terhadap nilai perusahaan. Harga saham dipengaruhi oleh kondisi dan posisi keuangan yang tertuang dalam laporan keuangan peusahaan. Dengan demikian, penting bagi manajemen perusahaan untuk selalu berusaha meningkatkan nilai perusahaan.

Tujuan utama perusahaan adalah meningkatkan nilai perusahaan. Nilai perusahaan tercermin di dalam harga saham perusahaan. Jika kegiatan perusahaan berjalan dengan baik, maka nilai perusahaan akan meningkat dan akan memberikan pengaruh positif bagi kelangsungan hidup perusahaan. Banyak faktor yang mempengaruhi nilai perusahaan, yang mana penelitian mengenai faktor-faktor yang berpengaruh terhadap nilai perusahaan sendiri telah banyak dilakukan, antara lain kinerja keuangan suatu perusahaan, kebijakan deviden, corporate governance dan lain sebagainya.

Salah satu hal yang berhubungan erat dengan nilai perusahaan adalah kinerja keuangan perusahaan. Kinerja keuangan perusahaan menunjukkan kapabilitas perusahaan di dalam mengelola sumber daya keuangan yang dimiliki oleh perusahaan. Kinerja keuangan yang baik ditunjukkan oleh seberapa tinggi perusahaan dalam meciptakan laba bagi perusahaan. Kemampuan perusahaan untuk dapat menciptakan laba yang tinggi memberikan dampak positif bagi perusahaan. Perusahaan menjadi semakin menarik di mata investor sehingga hal tersebut dapat mempengaruhi harga saham perusahaan. Hal tersebut sesuai dengan penelitian yang dilakukan oleh Putri \& Suwitho (2015), Wijaya \& Linawati (2015), serta Heder \& Priyadi (2017) yang menyatakan bahwa kinerja keuangan berpengaruh signifikan terhadap nilai perusahaan.

Di dalam upaya meningkatkan kinerja keuangan, perusahaan tidak jarang menggunakan sumber dana eksternal perusahaan dalam bentuk utang. Di dalam Pecking Order Theory yang dikemukakan oleh Donaldson pada tahun 1961 menyatakan bahwa pendanaan perusahaan dapat diperoleh dari tiga sumber yaitu laba ditahan, utang, dan penerbitan saham baru (Hanafi, 2010). Di dalam penelitian yang dilakukan oleh Brimantyo et.al (2014), menyatakan bahwa dividen berpengaruh positif terhadap nilai perusahaan. Dividen yang dibagikan kepada para investor berasal dari laba perusahaan selama periode tertentu. Hasil penelitian tersebut membuktikan bahwa pembagian dividen merupakan hal yang penting sehingga perusahaan tidak bisa dengan mudah dalam menggunakan laba perusahaan untuk modal tambahan. Dengan demikian perusahaan dapat menggunakan opsi kedua yaitu dengan menggunakan sumber dana eksternal yaitu utang.

Penggunaan utang diharapkan mampu untuk meningkatkan kinerja keuangan perusahaan. Di dalam penelitian yang dilakukan oleh Valentina \& Ruzikna (2017), Utami (2016), dan Nirajini \& Priya (2013) menyatakan bahwa struktur utang berpengaruh signifikan terhadap kinerja perusahaan. Dengan demikian dapat disimpulkan bahwa pentingnya perusahaan di dalam menggunakan sumber dana utang untuk dapat meningkatkan kinerja keuangan perusahaannya sehingga dapat mendapatkan laba yang lebih besar. Hal tersebut sesuai dengan teori proposisi Modigliani Miller II dimana di dalam teori tersebut dinyatakan bahwa nilai harapan dari peningkatan hasil terhadap modal akan bertambah seiring dengan peningkatan utang perusahaan (Hanafi, 2010). Hasil penelitian yang berbeda dikemukakakn oleh Budiasa, dkk (2016), Nassar (2016), dan Vatavu (2015) yang menyatakan bahwa struktur utang memiliki pengaruh negatif terhadap kinerja keuangan perusahaan. Hal ini menjadi research gap di dalam sehingga perlunya diteliti lebih lanjut mengenai hubungan antara struktur modal dan kinerja keuangan perusahaan. 
Penggunaan utang oleh perusahaan tidak hanya bertujuan untuk meningkatkan kinerja keuangan perusahaan, akan tetapi juga untuk memberikan signal kepada investor maupun calon investor. Signalling Theory yang dikembangkan oleh Ross pada 1977 memberikan model di mana penggunaan utang merupakan signal yang diberikan oleh perusahaan kepada pasar. Perusahaan ingin memberitahukan kepada pasar bahwa perusahaan memiliki prospek yang baik dan memiliki proyek yang akan dikerjakan sehingga membutuhkan tambahan dana berupa utang. Selain itu, penggunaan utang juga bertujuan untuk memberikan signal agar pasar lebih percaya bahwa perusahaan tersebut merupakan perusahaan yang kredibel (Hanafi, 2010). Informasi yang baik dapat berpengaruh positif terhadap harga saham di pasar, sehingga dengan demikian dapat disimpulkan bahwa penggunaan hutang berpengaruh positif terhadap nilai perusahaan.

Penggunaan utang oleh perusahaan juga dapat berdampak buruk bagi perusahaan. Para investor dan calon investor tidak selalu menganggap penggunaan utang sebagai signal positif, justru sebaliknya. Investor dan calon investor dapat berpikir bahwa perusahaan sedang mengalami financial distress sehingga memerlukan utang untuk menanggulangi kesulitan keuangan yang sedang dialami. Apabila signal yang diterima oleh para investor dan calon investor diintepretasikan seperti itu, maka penggunaan utang oleh perusahaan dapat memberikan dampak buruk bagi harga saham perusahaan. Dengan demikian dapat disimpulkan bahwa terdapat theory gap mengenai utang sehingga perlu dilakukan penelitian lanjutan untuk mengkonfirmasi teori tersebut.

Salah satu sektor perusahaan yang menggunakan hutang cukup tinggi adalah perusahaan yang bergerak di sektor property \& real estate. Penggunaan utang yang tinggi diiringi dengan risiko yang tinggi pula. Akan tetapi, perusahaan yang bergerak di sektor property \& real estate memiliki keunikan tersendiri. Harga property dari tahun ke tahun selalu naik, sehingga krediturpun tidak memiliki kekhawatiran terhadap perusahaan yang bergerak di sektor property \& real estate di dalam kemampuannya membayarkan utang. Hal ini yang menjadikan perusahaan yang bergerak di sektor property \& real estate cenderung memiliki struktur modal dimana proporsi utangnya termasuk tinggi bahkan bisa melebihi $50 \%$.

Selain itu, pemerintah Indonesia sedang giat dalam membangun infrastruktur daerah, mulai dari pembangunan jalan raya hingga program rumah subsidi. Adanya program tersebut tentu saja berdampak bagi perusahaanperusahaan yang bergerak di sektor property \& real estate. Fenomena tersebut yang melandasi peneliti dalam melakukan penelitian di sektor property \& real estate. Berdasarkan uraian tersebut, maka tujuan penelitian ini adalah untuk menganalisis dan menjelaskan pengaruh struktur modal terhadap kinerja keuangan dan nilai perusahaan, serta menganalisis dan menjelaskan pengaruh kinerja keuangan terhadap nilai perusahaan.

\section{Metode Penelitian}

Jenis penelitian yang digunakan di dalam penelitian ini adalah jenis penelitian kuantitatif dengan pendekatan explanatory research. Penelitian di lakukan pada perusahaan sektor real estate yang listing di Bursa Efek Indonesia pada tahun 2012 - 2016 yang berjumlah enam perusahaan. Alat analisis data yang digunakan di dalam penelitian ini adalah partial least square. Analisis tersebut dibagi menjadi dua analisis utama yaitu outer model test dan inner model test. (Ghozali, 2006)

\section{Hasil Penelitian}

\section{Evaluasi Outer Model}

Beberapa uji yang dilakukan pada outer model antara lain adalah Convergent Validity, Discriminant Validity, dan Composite Reliability dan Cronbach Alpha. Berikut adalah hasil evaluasi outer model : 


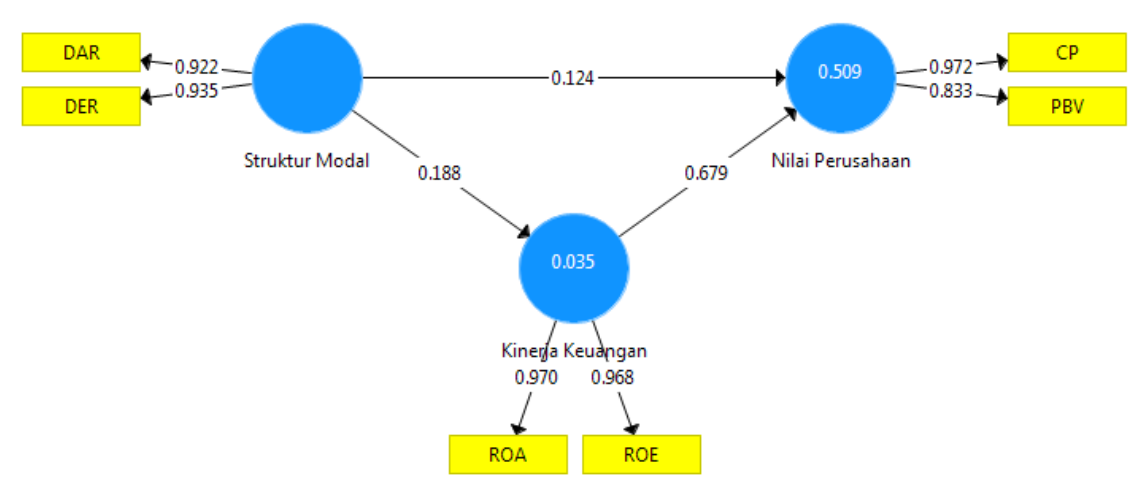

Gambar 1 Outer Model Test

Dari hasil kalkulasi PLS Alogarithm terlihat bahwa semua indikator yang digunakan di dalam penelitian ini memiliki nilai faktor loading di atas 0,6 . Dengan demikian model serta item penelitian tersebut dinyatakan valid dapat dilanjutkan ke tahap selanjutnya.

Tabel 1. Average Variance Extracted (AVE)

\begin{tabular}{lc}
\multicolumn{1}{c}{ Konstruk } & AVE \\
\hline Struktur Modal $(\mathrm{X} 1)$ & 0,938 \\
Kinerja Keuangan (Y1) & 0,819 \\
Nilai Perusahaan (Y2) & 0,862 \\
\hline
\end{tabular}

Sumber : Data diolah (2018)

Pada penelitian ini nilai AVE masing-masing konstruk berada di atas 0,5 , sehingga tidak ada permasalahan convergent validity pada model yang diuji. Dikarenakan tidak adanya masalah permasalahan convergent validity, maka berikutnya yang diuji adalah permasalahan yang terkait dengan discriminant validity.

Tabel 2. Discriminant validity

\begin{tabular}{lrrr}
\hline & Struktur Modal & Kinerja Keuangan & Nilai Perusahaan \\
\hline Struktur Modal & $\mathbf{0 , 9 6 9}$ & & \\
Kinerja Keuangan & 0,703 & $\mathbf{0 , 9 0 5}$ & \\
Nilai Perusahaan & 0,188 & 0,251 & $\mathbf{0 , 9 2 9}$ \\
\hline
\end{tabular}

Sumber : Data diolah (2018)

Berdasarkan tabel 5.8 di atas, terlihat bahwa nilai akar kuadarat dari AVE masing-masing variabel lebih besar dari korelasi masing-masing konstruk. Dengan demikian dapat disimpulkan adanya discriminant validity yang baik.

Tabel 3 Composite Reliability dan Cronbach's Alpha

\begin{tabular}{lcc}
\hline Construct & Composite Reliability & Cronbach's Alpha \\
\hline Struktur Modal & 0,968 & 0,934 \\
Kinerja Keuangan & 0,900 & 0,809 \\
Nilai Perusahaan & 0,926 & 0,841 \\
\hline
\end{tabular}

Sumber : Data diolah (2018)

Konstruk dinyatakan reliabel apabila memiliki nilai composite reliability di atas 0,70 dan cronbach's alpha di atas 0,60 . Dari hasil output di atas, semua konstruk memiliki nilai composite reliability di atas 0,70 dan nilai cronbach's alpha di atas 0,60 . Dengan demikian, dapat disimpulkan bahwa konstruk memiliki reliabilitas yang baik.

\section{Evaluasi Inner Model (Uji Hipotesis)}

Pengujian inner model PLS pada intinya adalah menguji hipotesis dalam penelitian. Dalam penelitian ini memiliki tiga bagian pengujian hipotesis. Pengujian dilakukan dengan uji t seperti pada analisis regresi, jika diperoleh nilai t di atas 1,96 maka dapat disimpulkan pengaruh antar variabel terbukti signifikan, begitu pula 
sebaliknya jika nilai t dibawah 1,96 maka pengaruh variabel tidak signifikan (taraf signifikansi $5 \%$ ). Model struktural dalam PLS dievaluasi dengan menggunakan R2 untuk variabel dependen dan nilai koefisien path untuk variabel independen yang kemudian dinilai taraf signifikansinya berdasarkan t-statistic dari masing-masing jalur. Adapun model struktural penelitian ini dapat dilihat pada gambar berikut :

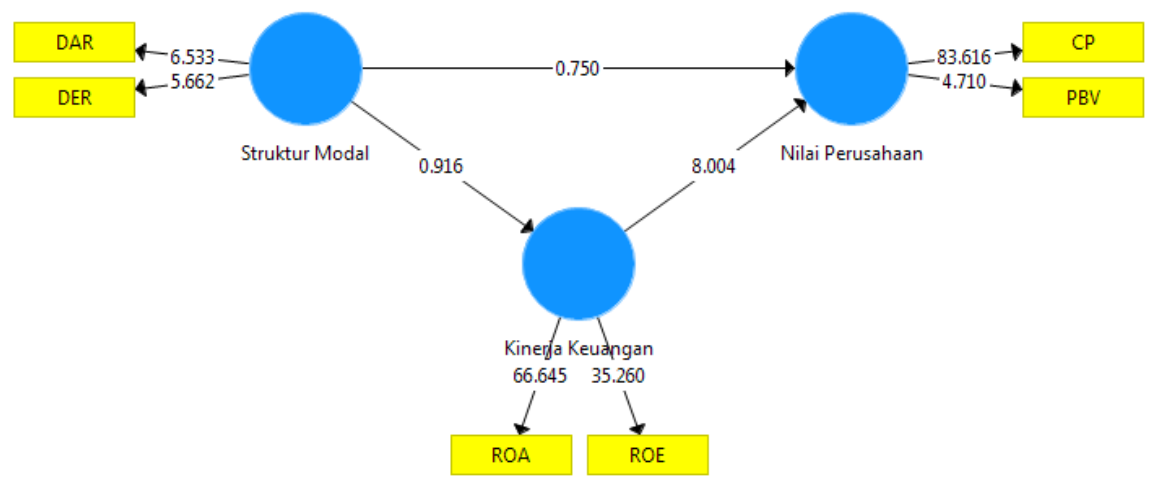

Gambar 2 Inner Model Test

Untuk menilai signifikansi model prediksi dalam pengujian struktural, dapat dilihat dari nilai t-statistic antara variabel independen terhadap variabel dependen dalam tabel Path Coefficients di bawah ini:

Tabel 4 Path Coefficients (Mean, STDEV, t-Value)

\begin{tabular}{lcccc}
\hline & $\begin{array}{c}\text { Original } \\
\text { Sample }\end{array}$ & Sample Mean & $\begin{array}{c}\text { Standard } \\
\text { Deviation }\end{array}$ & t-Statistic \\
\hline Struktur Modal $\rightarrow$ Kinerja & 0,188 & 0,234 & 0,217 & 0,916 \\
Keuangan & 0,124 & 0,099 & 0,164 & 0,750 \\
Struktur Modal $\rightarrow$ Nilai Perusahaan & 0,679 & 0,711 & 0,085 & 8,004 \\
Kinerja Keuangan $\rightarrow$ Nilai & & &
\end{tabular}

Sumber : Data diolah (2018)

Pada gambar 2 dan tabel 4 terlihat bahwa terdapat satu pengaruh signifikan dan dua pengaruh tidak signifikan pada hasil penelitian ini. Berdasarkan hasil pengujian hipotesis secara statistik, maka dapat dijelaskan sebagai berikut :

- Struktur Modal memiliki pengaruh positif terhadap Kinerja Keuangan. Hal tersebut tercermin dalam nilai koefisien jalur (original sample) yaitu 0,188 yang bernilai positif. Selain itu, Struktur Modal berpengaruh tidak signifikan terhadap Kinerja Keuangan ditunjukkan dengan nilai t-statistic sebesar 0,675 lebih rendah dari ttable yaitu 1,96.

- Struktur Modal memiliki pengaruh positif terhadap Nilai Perusahaan. Hal tersebut tercermin dalam nilai koefisien jalur (original sample) yaitu 0,124 yang bernilai positif. Selain itu, Struktur Modal berpengaruh tidak signifikan terhadap Nilai Perusahaan ditunjukkan dengan nilai t-statistic sebesar 0,756 lebih rendah dari ttable yaitu 1,96

- Kinerja Keuangan memiliki pengaruh positif terhadap Nilai Perusahaan. Hal tersebut tercermin dalam nilai koefisien jalur (original sample) yaitu 0,679 yang bernilai positif. Selain itu, Kinerja Keuangan berpengaruh signifikan terhadap Nilai Perusahaan ditunjukkan dengan nilai t-statistic sebesar 8,004 lebih besar dari t-table yaitu 1,96 .

\section{Pengaruh Tidak Langsung}

Selain menguji hubungan antar variabel, penelitian ini juga bertujuan untuk menganalisis dan menjelaskan pengaruh tidak langsung (Indirect Effect) dari variabel Struktur Modal terhadap Nilai Perusahaan melalui Kinerja Keuangan. Berdasarkan hasil analisis data, maka diketahui pengaruh tidak langsung dari penelitian ini adalah sebagai berikut : 
Tabel 5 Pengaruh Tidak Langsung (Indirect Effect)

\begin{tabular}{cccc}
$\begin{array}{c}\text { Original } \\
\text { Sample }\end{array}$ & Sample Mean & $\begin{array}{c}\text { Standard } \\
\text { Deviation }\end{array}$ & t-Statistic \\
0.127 & 0.152 & 0.145 & 0.881 \\
\hline
\end{tabular}

Sumber : Data diolah (2018)

Berdasarkan data tersebut, maka dapat disimpulkan bahwa Struktur Modal berpengaruh positif terhadap Nilai Perusahaan melalui Kinerja Keuangan. Hal tersebut ditunjukkan oleh nilai path coefficient sebesar 0.127 yang bernilai positif. Selain itu, kepemimpinan Struktur Modal tidak signifikan terhadap Nilai Perusahaan melalui Kinerja Keuangan. Hal tersebut ditunjukkan dengan nilai t-statistic sebesar 0,881, di bawah t-tabel yaitu 1,96. Dengan demikian dapat disimpulkan bahwa variabel Kinerja Keuangan merupakan variabel part mediation karena di dalam penelitian ini variabel Struktur Modal tidak dapat mempengaruhi variabel Nilai Perusahaan baik melalui atau tanpa melalui variabel Kinerja Keuangan sebagai variabel mediator.

\section{Godness of Fit Index (GoF)}

Godness of fit model diukur dengan menggunakan Q2 yang dihitung berdasarkan R2 masing-masing variabel laten dependen dengan intepretasi yang sama dengan regresi. Hasil perhitungan R2 pada penelitian ini adalah sebagai berikut :

Tabel 6 Koefisien Determinasi $\left(R^{2}\right)$

\begin{tabular}{lc}
\hline \multicolumn{1}{c}{ Variabel } & $\mathbf{R}^{\mathbf{2}}$ \\
\hline Kinerja Keuangan & 0,035 \\
Nilai Perusahaan & 0,509 \\
\hline
\end{tabular}

Sumber : Data diolah (2018)

Selanjutnya setelah diketahui nilai dari masing-masing $R^{2}$, maka dapat dihitung nilai $\mathrm{Q}^{2}$ untuk mengetahui sejauh mana keragaman data yang dapat dijelaskan oleh model penelitian ini. Perhitungan $Q^{2}$ dalam penelitian ini adalah sebagai berikut:

$$
\begin{aligned}
& Q^{2}=1-\left(1-R^{2} Y 1\right)\left(1-R^{2} Y 2\right) \\
& Q^{2}=1-(1-0,035)(1-0,509) \\
& Q^{2}=1-(0,965)(0,491) \\
& Q^{2}=1-0,473 \\
& Q^{2}=0,527 \text { atau } 52,7 \%
\end{aligned}
$$

Berdasarkan hasil perhitungan di atas, nilai $\mathrm{Q}^{2}$ adalah sebesar 0,527 atau 52,7\%. Maka dapat disimpulkan bahwa kerjagaman data yang dapat dijelaskan oleh model penelitian ini adalah sebesar 52,7\%. Dengan kata lain, informasi yang terkandung di dalam data $52,7 \%$ dapat dijelaskan oleh model tersebut, sedangkan sisanya yaitu sebesar $47,3 \%$ dijelaskan oleh variabel lain yang belum terkandung di dalam model penelitian ini

\section{Pembahasan}

\section{Pengaruh Struktur Modal terhadap Kinerja Keuangan}

Berdasarkan hasil perhitungan statistik yang dilakukan dengan menggunakan Partial Least Square (PLS), dapat diketahui bahwa struktur modal memiliki pengaruh positif terhadap kinerja keuangan. Hal tersebut dapat diketahui dari nilai koefisien jalur (original sample) sebesar 0,188 yang bernilai positif. Selanjutnya, struktur modal berpengaruh tidak signifikan terhadap kinerja keuangan. Hal tersebut diketahui dari nilai t-statistik yang diperoleh sebesar 0,916 lebih kecil dari t-tabel yaitu 1,96.

Hasil tersebut dapat disimpulkan bahwa peran struktur modal dalam meningkatkan kinerja keuangan perusahaan sangat kecil. Hal tersebut bisa terjadi karena perusahaan sudah dapat menghasilkan keuntungan 
dengan baik, atau penggunaan utang tidak dapat dimaksimalkan oleh manajemen perusahaan sehingga pengaruh dari penggunaan utang tidak signifikan. Hasil penelitian ini tidak mendukung hasil penelitian yang dilakukan oleh Valentina \& Ruzikna (2017), Utami (2016), dan Nirajini \& Priya (2013) menyatakan bahwa struktur utang berpengaruh signifikan terhadap kinerja perusahaan.

\section{Pengaruh Struktur Modal terhadap Nilai Perusahaan}

Berdasarkan hasil perhitungan statistik yang dilakukan dengan menggunakan Partial Least Square (PLS), dapat diketahui bahwa struktur modal memiliki pengaruh positif terhadap nilai perusahaan. Hal tersebut dapat diketahui dari nilai koefisien jalur (original sample) sebesar 0,124 yang bernilai positif. Selanjutnya, struktur modal berpengaruh tidak signifikan terhadap kinerja keuangan. Hal tersebut diketahui dari nilai t-statistik yang diperoleh sebesar 0,750 lebih kecil dari t-tabel yaitu 1,96.

Hasil tersebut dapat disimpulkan bahwa struktur modal tidak memiliki pengaruh yang cukup berarti terhadap nilai perusahaan. Hal tersebut bisa terjadi karena investor tidak terlalu peduli mengenai bagaimana struktur modal perusahaan selama perusahaan masih dapat beroperasi dan menghasilkan laba. Dengan demikian nilai perusahaan yang tercermin dari closing price tidak terpengaruh atas perubahan struktur modal perusahaan.

\section{Pengaruh Kinerja Keuangan terhadap Nilai Perusahaan}

Berdasarkan hasil perhitungan statistik yang dilakukan dengan menggunakan Partial Least Square (PLS), dapat diketahui bahwa kinerja keuangan memiliki pengaruh positif terhadap kinerja keuangan. Hal tersebut dapat diketahui dari nilai koefisien jalur (original sample) sebesar 0,679 yang bernilai positif. Selanjutnya, struktur modal berpengaruh tidak signifikan terhadap kinerja keuangan. Hal tersebut diketahui dari nilai t-statistik yang diperoleh sebesar 8,004 lebih besar dari t-tabel yaitu 1,96.

Hasil tersebut dapat disimpulkan bahwa kinerja keuangan perusahaan memiliki peran penting dalam menjaga ataupun meningkatkan nilai perusahaan. Para investor akan selalu melihat kemampuan perusahaan dalam menghasilkan laba. Dengan demikian, perlu dilakukan upaya lebih lanjut oleh perusahaan untuk terus selalu meningkatkan kinerja keuangan perusahaannya. Hasil penelitian ini mendukung penelitian yang dilakukan oleh Putri \& Suwitho (2015), Wijaya \& Linawati (2015), serta Heder \& Priyadi (2017) yang menyatakan bahwa kinerja keuangan berpengaruh signifikan terhadap nilai perusahaan.

\section{Pengaruh Struktur Modal terhadap Nilai Perusahaan melalui Kinerja Keuangan}

Struktur Modal berpengaruh positif terhadap Nilai Perusahaan melalui Kinerja Keuangan. Hal tersebut ditunjukkan oleh nilai path coefficient sebesar 0.127 yang bernilai positif. Selain itu, kepemimpinan Struktur Modal tidak signifikan terhadap Nilai Perusahaan melalui Kinerja Keuangan. Hal tersebut ditunjukkan dengan nilai tstatistic sebesar 0,881, di bawah t-tabel yaitu 1,96. Dengan demikian dapat disimpulkan bahwa variabel Kinerja Keuangan merupakan variabel part mediation karena di dalam penelitian ini variabel Struktur Modal tidak dapat mempengaruhi variabel Nilai Perusahaan baik melalui atau tanpa melalui variabel Kinerja Keuangan sebagai variabel mediator

\section{Kesimpulan}

Berdasarkan penelitian yang telah dilakukan, maka terdapat empat kesimpulan kesimpulan yang diperoleh dari penelitian ini. Pertama, struktur modal berpengaruh positif dan tidak signifikan terhadap kinerja keuangan perusahaan. Penggunaan utang tidak memiliki kontribusi secara signifikan terhadap kinerja keuangan perusahaan dapat disebabkan oleh berbagai hal. Hal tersebut bisa terjadi karena perusahaan sudah dapat menghasilkan keuntungan dengan baik, atau penggunaan utang tidak dapat dimaksimalkan oleh manajemen perusahaan. Hasil ini mengkonfirmasi teori proposisi Modigliani Miller II yang menyatakan bahwa terdapat hubungan positif antara penggunaan utang dan kinerja keuangan perusahaan. 
Kedua, struktur modal berpengaruh positif dan tidak signifikan terhadap nilai perusahaan. Pengaruh positif tersebut mengkonfirmasi bahwa ada pengaruh dari penggunaan utang terhadap nilai perusahaan meskipun pengaruhnya tidak signifikan. Hasil penelitian ini mendukung Signalling Theory dari Ross yang menyatakan bahwa penggunaan utang merupakan signal positif bagi perusahaan sehingga akan berdampak baik bagi harga saham. Lebih lanjut, pengaruh yang tidak signifikan antara struktur modal dan nilai perusahaan disebabkan Investor dan calon investor tidak terlalu memperdulikan mengenai besar kecilnya utang perusahaan selama perusahaan bisa mencetak laba dalam operasinya.

Ketiga, kinerja keuangan berpengaruh positif dan signifikan terhadap nilai perusahaan. Perusahaan perlu memberikan perhatian khusus terhadap kinerja keuangannya. Kinerja keuangan perusahaan menunjukkan kemampuan perusahaan dalam mengelola keuangan perusahaan dalam menghasilkan laba. Laba yang dihasilkan perusahaan merupakan salah satu faktor penting bagi investor dan calon investor dalam pertimbangan keputusan investasi yang dilakukannya.

Keempat, Struktur modal berpengaruh positif dan tidak signifikan terhadap nilai perusahaan melalui kinerja keuangan perusahaan. Baik secara langsung maupun tidak langsung, struktur modal tidak memiliki pengaruh signifikan terhadap nilai perusahaan. dapat disimpulkan bahwa investor dan calon investor di perusahaan yang bergerak di sektor property \& real estate tidak terlalu mempermasalahkan mengenai jumlah utang maupun struktur modal perusahaan. Perusahaan yang bergerak di sektor property \& real estate dianggap memiliki kredibilitas yang tinggi sehingga investor dan calon investor tidak perlu meragukan kemampuan perusahaan di dalam menghasilkan laba dan membayar utangnya.

\section{Daftar Pustaka}

Brimantyo, Harril., Suhadak., Nuzula, Nila Firdausi. 2014. "The Influence Of Fundamental Factors On Dividend Policies And Firm Value (Studies At Companies Listed In Indonesian Stock Exchange Period 2008 - 2012)". PROFIT JURNAL ADMINISTRASI BISNIS, 8(2). http://dx.doi.org/10.9876/10.9876NOL1ISSN1978-743X

Budiasa, I Ketut., Purbawangsa, Ida Bagus Anom., dan Rahyuda, Henny. 2016. "Pengaruh Risiko Usaha dan Struktur Modal Terhadap Pertumbuhan Aset Serta Profitabilitas Pada Lembaga Perkreditan Desa". Jurnal Ekonomi dan Bisnis Universitas Udayana Vol. 5 No. 7: 1919 - 1952. ISSN: 2337 - 3067

Ghozali, Imam. 2006. Structural Equation Modeling Metode Alternatif dengan Partial Least Square. Badan Penerbit Universitas Diponegoro, Semarang

Hanafi, Mamduh M. 2010. Manajemen Keuangan. Edisi Pertama. Yogyakarta: BPFE

Heder dan Priyadi, Maswar Patuh. 2017. "Pengaruh Kinerja Keuangan Terhadap Nilai Perusahaan dengan Good Corporate Governance Sebagai Variabel Pemoderasi”. Jurnal IImu dan Riset Akuntansi Vol. 6 No. 7: 1 25. ISSN : $2460-0585$

Modigliani, Franco \& Miller, M.H. 1958. "The Cost of Capital, Corporation Finance and The Theory of Investment". The American Economic Review. 13(3): 261- 297.

Nassar, S. 2016. "The Impact of Capital Structure on Financial Performance of The Firms: Evidence From Borsa Istanbul". Journal of Business \& Financial Affairs Vol. 5 No. 2: 1 - 4. ISSN: 2167 - 0234

Nirajini, A., and Priya, K.B. 2013. "Impact of Capital Structure on Financial Performance of The Listed Trading Companies in Sri Lanka". International Journal of Scientific and Research Publications Vol. No. 5: 1 - 9. ISSN: $2250-3153$

Putri, Ayu Oktyas., dan Suwitho. 2015. "Pengaruh Kinerja Keuangan Terhadap Nilai Perusahaan dengan Pengungkapan CSR Sebagai Variabel Pemoderasi”. Jurnal IImu Riset dan Manajemen Vol. 4 No. 4: 1 - 19

Utami, Fitri Cinta. 2016. Pengaruh Struktur Modal, Kondisi Ekonomi (Inflasi), dan Risiko Bisnis terhadap Kinerja Keuangan Perusahaan Manufaktur yang Terdaftar di Bursa Efek Indonesia Tahun 2011-2015

Valentina, Henni., dan Ruzikna. 2017. "Pengaruh Struktur Modal, Risiko Bisnis dan Pertumbuhan Penjualan Terhadap Kinerja Keuangan Pada Perusahaan Real Estate dan Property yang Terdaftar di Bursa Efek Indonesia Tahun 2010-2014". JOM FISIP Vol. 4 No. 2: 1 - 15 
Vatavu, Sorana. 2015. "The Impact of Capital Structure on Financial Performance in Romanian Listed Companies". Procedia Economics and Finance Vol. 32: 1314 - 1322

Wijaya, Anthony., dan Linawati, Nanik. 2015. "Pengaruh Kinerja Keuangan terhadap Nilai Perusahaan". FINESTA Vol. 3 No. $1: 46-51$ 